\title{
Geochemical and faunal proxies in the Westphalian A (Langsettian) marine horizon of the Lublin Coal Basin
}

\author{
Ewa KRZESZOWSKA ${ }^{1, *}$ \\ 1 Silesian University of Technology Institute of Applied Geology, Akademicka 2, 44-100 Gliwice, Poland
}

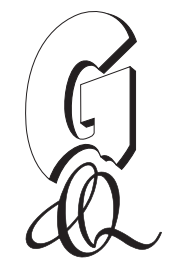

Krzeszowska, E., 2017. Geochemical and faunal proxies in the Westphalian A (Langsettian) marine horizon of the Lublin Coal Basin. Geological Quarterly, 61 (4): 751-764, doi: 10.7306/gq.1374

The uppermost Westphalian marine horizon (Dunbarella horizon) is especially important for correlation of Carboniferous deposits in the Lublin Coal Basin and in other basins of the Northwest European Carboniferous Basin. The Dunbarella horizon is characterized by cyclic sedimentation and consequent faunal spectrum variability, typical for Westphalian marine horizons of northwestern Europe. Palaeontological study of the Dunbarella horizon showed the presence of macrofauna representing different palaeoenvironments, from marine to brackish (non-marine) and freshwater conditions. The vertical sea level fluctuations and changes in seawater salinity resulting in palaeontological record changes do not link with geochemical proxies. TOC, redox-sensitive trace element concentrations, and $\mathrm{V} / \mathrm{Cr}$, Ni/Co and $\mathrm{V} /(\mathrm{V}+\mathrm{Ni})$ ratios generally suggest that the Dunbarella horizon sediments were deposited under predominantly oxic conditions (with local exceptions during the initial phase of the Dunbarella ingression; Kopina 1 borehole).

Key words: inorganic geochemistry, palaeoredox conditions, Dunbarella horizon, Lublin Coal Basin.

\section{INTRODUCTION}

The Northwest European Carboniferous Basin (NWECB) is a large sedimentary basin extending from Ireland in the west to Poland in the east. It developed north of the Variscan Rheno-Hercynian belt (Kombrink, 2008). Geology of the NWECB has been extensively studied by many authors because of its economic importance the Pennsylvanian coal-bearing (mainly Westphalian) series (e.g., Calver, 1968; Leeder, 1988; Narkiewicz, 2007; Kombrink, 2008). Nowadays, the most prospective area for coal deposits of the NWECB is the Lublin Coal Basin (LCB) located in Poland, in the eastern part of the basin.

The most important part of the coal-bearing Carboniferous series of LCB is the Lublin Formation (Pennsylvanian, Westphalian $A$ and $B$ ) containing the main multi-seam coal deposits (Porzycki and Zdanowski, 1995).

Only one coal mine operates in the LCB, and it encompasses $\sim 0.8 \%$ of the total coal basin area. Currently, due to the investor interest, intensive geological research of the deposits has been conducted. Within the Lublin Coal Project, the Prairie Mining Limited Company has focused on the development and operation of a new coal mine in the Lublin Coal Basin. One of the most important stages of the geological research is the

\footnotetext{
* E-mail: Ewa.Krzeszowska@polsl.pl

Received: April 9, 2017; accepted: July 9, 2017; first published online: August 27, 2017
}

identification of the Dunbarella marine marker horizon that can be found in the lower part of the Lublin Formation. Therefore, it constitutes the most important section for correlation and exploration of the deposits in the LCB. Furthermore, since the Dunbarella marine marker horizon has its equivalents in other coalfields of the Northwest European Carboniferous Basin, it is a significant marker horizon for the whole region. The identification of this faunal horizon is essential for the recognition of coal deposits in the LCB.

Palaeontological studies of the Dunbarella horizon have been presented by many authors. So far, detailed palaeontological study is the only method for its identification (Musiał et al., 1995; Musiał and Tabor, 2001; Krzeszowska, 2015 and references cited therein).

Laterally extensive marine horizons that occur within paralic sequences (e.g., Dunbarella marine horizon) are generally regarded as reliable correlative stratigraphic markers in the Pennsylvanian coalfields. These horizons are represented typically by goniatite-bearing black shales characterized by high $U$ and Mo levels, and interpreted as deposited during times of anoxia (Fisher and Wignall, 2001; Kombrink, 2008; Kombrink et al., 2008; Pearce et al., 2010). Enrichment in redox-sensitive trace elements, and high TOC and S contents allow identification of the oxygen-restricted environments (e.g., Kombrink, 2008; Fisher and Wignall, 2001; Zatoń et al., 2009; Pearce et al., 2010; Racka et al., 2010; Marynowski et al., 2012).

Therefore, the main goals of the study were to (1) determine the palaeoredox conditions of the Dunbarella marine horizon, (2) compare the geochemical data with the palaeontological record, and (3) test, whether inorganic geochemistry can be used for identification and correlation of the Dunbarella marine horizon. 


\section{GEOLOGICAL SETTING}

The Lublin Coal Basin is located in south-east Poland. The Lviv-Volhynia Coal Basin is its continuation in Ukraine. It is situated at the contact zone of two major geological units: the Precambrian East European Platform and the Early Paleozoic West European Platform. The LCB is an extended province stretching from south-east to north-west, 20 to $40 \mathrm{~km}$ wide and $180 \mathrm{~km}$ long (Fig. 1). The sub-Carboniferous basement consists of Proterozoic crystalline rocks and Lower and Upper Paleozoic deposits. The Carboniferous strata, which lie discordantly on the older substrate, are represented by Middle Mississippian to Lower Pennsylvanian deposits (Fig. 2). They are overlain by a sequence of Permo-Mesozoic and Cenozoic rocks. The thickness of the overburden varies from 350 to $>1200 \mathrm{~m}$ (e.g., Porzycki and Zdanowski, 1995; Zdanowski, 1999).

The main hard coal-bearing series of the LCB, as well as the other basins of the NWECB, consists of the Westphalian deposits (representing mostly the Lublin Formation in the LCB). These are paralic deposits with multiple marine fauna horizons (mainly in the Westphalian A), which pass into brackish and then into continental deposits. The marine horizons are impor- tant marker horizons within a monotonous mudstone-claystone sequence of fluvial or lacustrine sediments. They form relatively thin (up to several metres in thickness) deposits being a record of marine or brackish sedimentary conditions (Leeder, 1988; Suess et al., 2007). The Dunbarella marine horizon, which is the subject of this study, is the most important marker horizon in the LCB (in Poland). It marks the boundary between the Westphalian A and B and between paralic and limnic sedimentation (Musiał et al., 1995; Krzeszowska, 2015). This marker horizon correlates with the Clay Cross Marine Band (England), the Katharina horizon (Germany and the Netherlands) and the Quaregnon horizon (Belgium). These are very important correlation horizons in northwestern and central Europe due to their very large extent, their common presence, and the fact that they are located within a sequence very rich in coal resources (Calver, 1968; Musiał et al., 1995; Kombrink, 2008; Krzeszowska, 2015). A distinctive feature of this horizon is cyclic sedimentation and associated variability of the fauna spectrum typical of the Westphalian marine fauna horizons (Krzeszowska, 2015). The cyclic sedimentation and consequent faunal spectrum variability in the profiles of marine horizons have been reported from the basins of northwestern and central Europe (Calver, 1968; Kombrink, 2008).

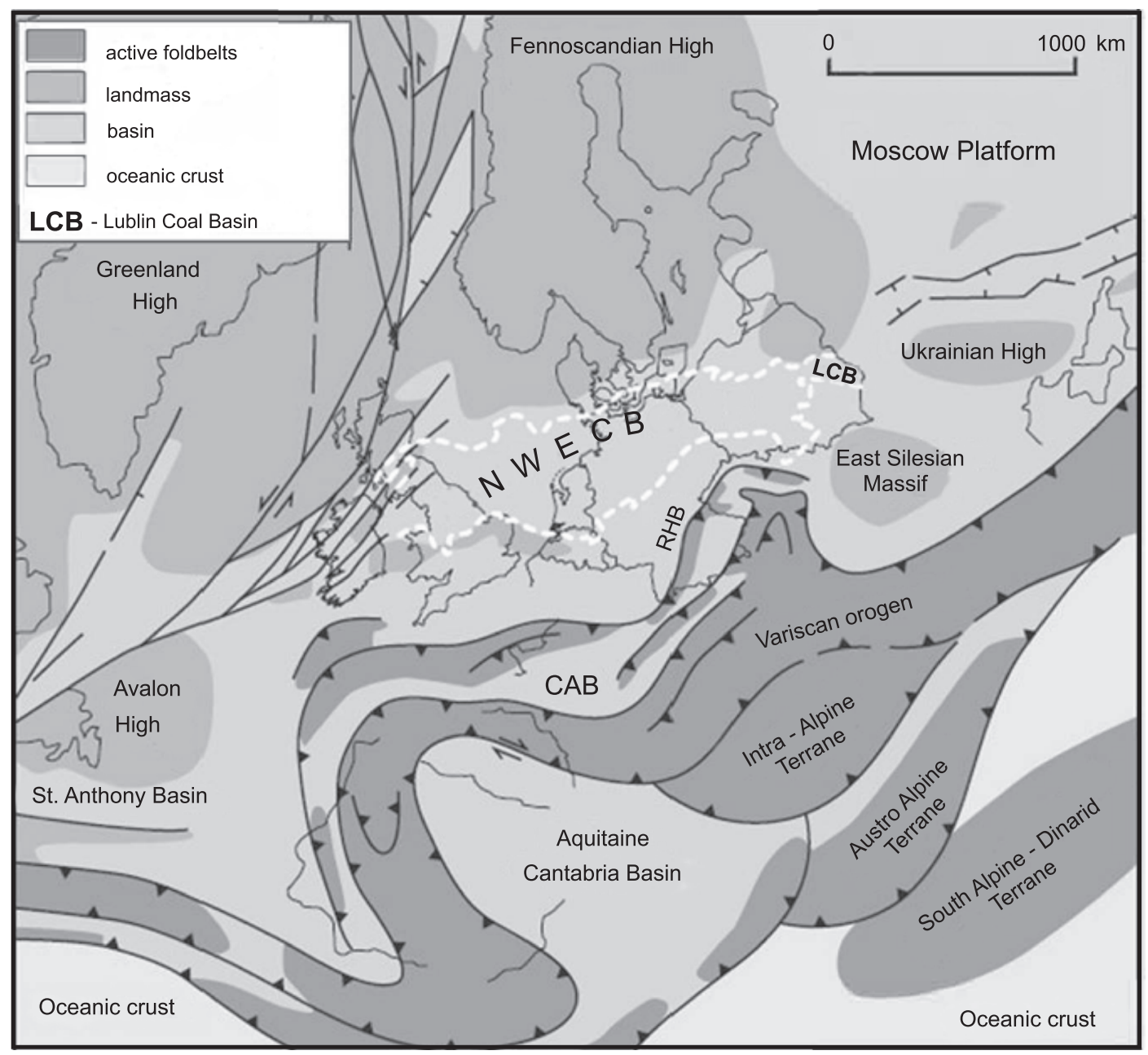

Fig. 1. Location of the Lublin Coal Basin (LCB) within the Northwest European Carboniferous Basin (NWECB)

The dashed white line indicates the present-day contours of the NWECB;

RHB - Rhenohercynian Basin, CAB - Central Armorican Basin (Kombrink, 2008, redrawn after Ziegler, 1989) 


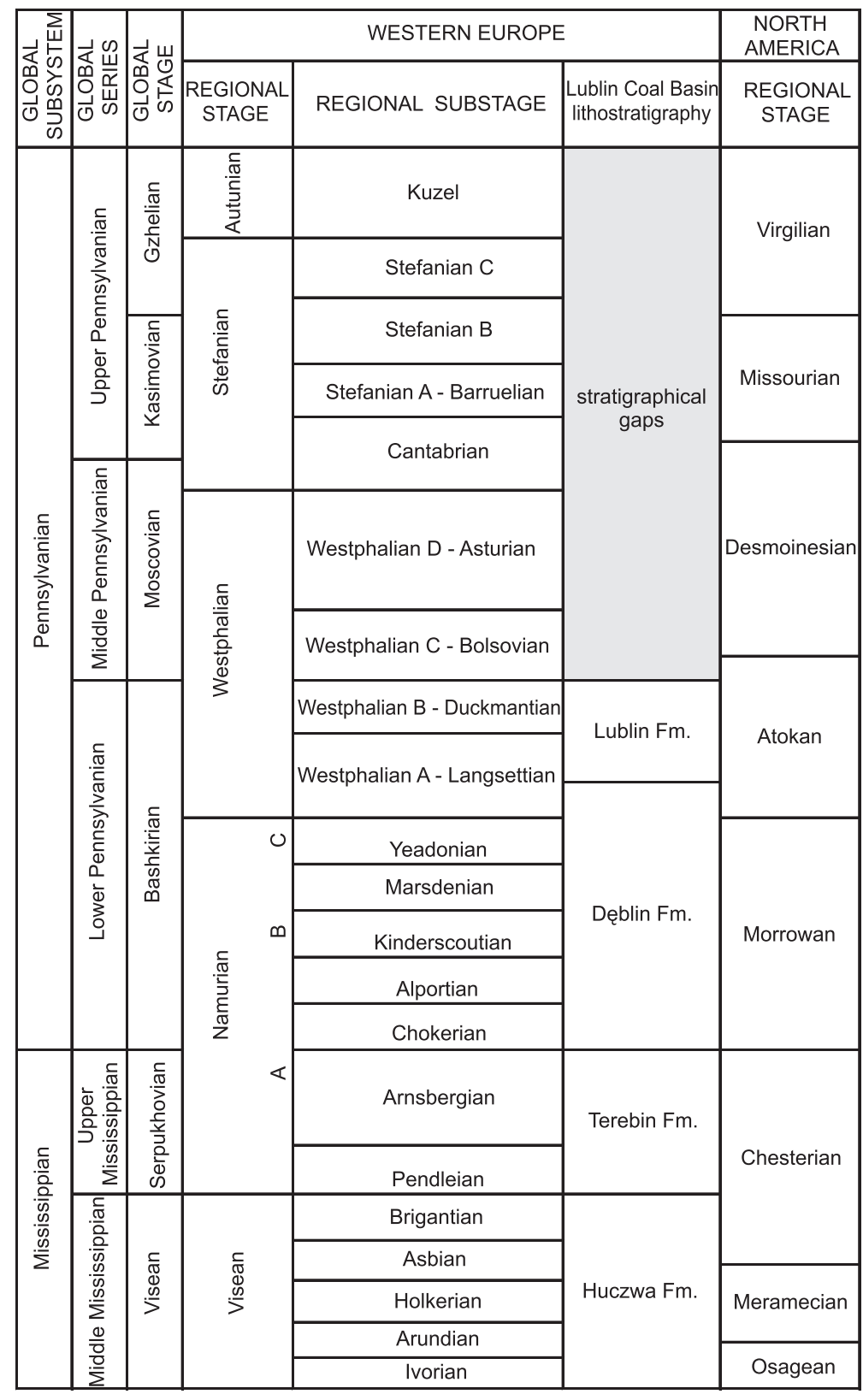

Fig. 2. Divisions of the Carboniferous succession in the Lublin Coal Basin and its correlation with the North America Regional Stage (simplified) (after Porzycki and Zdanowski, 1995; Dusar, 2006; Heckel and Clayton, 2006; Richards, 2013)

\section{MATERIALS AND METHODS}

The material studied comes from core samples from the Kopina 1, Borowo, Kulik and Syczyn 7 boreholes, located in the central part of the Lublin Coal Basin (Figs. 3 and 4). The study is based on data from 41 samples taken from the Dunbarella marine marker horizon.
The Dunbarella horizon is composed of grey claystones, locally sandy claystones or mudstones with thin carbonate and siderite interlayers (Fig. 5).

Sampling for the geochemical study followed a detailed palaeontological study of the horizon (Krzeszowska, 2015). Samples (claystones and sandy claystones) representing $0.2 \mathrm{~m}$ intervals of the profiles with different faunal record were selected for the geochemical study (Fig. 5).

The samples represent intervals of the Dunbarella horizon characterized by the following features (after Calver, 1968):

- abundant typical marine fauna represented mainly by bivalve and same goniatites and gastropods, with varying occurrence of brachiopods (mainly Lingula),

- abundant brackish fauna or fauna with high salinity tolerances, represented mainly by bivalves, with varying occurrence of brachiopods (mainly Lingula),

- abundant fauna represented mainly by brachiopods (Lingula),

- freshwater fauna or indeterminate remains of freshwater fauna,

- few faunal specimens, including primarily brachiopods and bivalves or indeterminate remains.

Sample preparation and analytical procedures were performed by the AcmeLab Analytical Laboratory (currently Bureau Veritas Commodities Canada Ltd), Vancouver, Canada, and the Oil and Gas Institute - National Research Institute (Kraków, Poland). Major and trace elements $(\mathrm{U}, \mathrm{TH}, \mathrm{Mo}, \mathrm{V}, \mathrm{Cr}, \mathrm{Co}, \mathrm{Ni}$, $\mathrm{Zn}, \mathrm{Cu}, \mathrm{Pb}, \mathrm{Fe}$ and $\mathrm{Al}$ ) were analysed using inductively coupled plasma mass spectrometry (ICP/MS) following 4-acid digestion ( $\mathrm{HF}+\mathrm{HClO}_{4}+\mathrm{HCl}+$ $+\mathrm{HNO}_{3}$ ). Contents of total sulphur (S) were obtained using a LECO analyser. Total organic carbon (TOC) was determined by Rock-Eval pyrolysis. Table providing chemical data, including methods and detection limits for each sample (Appendix 1*).

\section{RESULTS AND DISCUSSION}

\section{TOC-Fe-S RELATIONSHIPS}

The relationship between TOC (total organic carbon) vs. Fe vs. S has been extensively used to assess palaeoredox conditions in marine systems (e.g., Berner and Raiswell, 1984; Raiswell and Berner, 1986; Leventhal, 1987; Raiswell and Al-Biatty, 1989; Szczepanik et al., 2007; Algeo and Maynard, 2008; Zatoń et al., 2009; Racka et al., 2010; Marynowski et al., 2012; Wójcik-Tabol, 2015).

Total organic carbon, and total sulphur (S) and iron (Fe) contents are generally low in the Dunbarella horizon (Fig. 6, Table 1 and Appendix 1). Increased TOC, S and Fe contents were observed mainly in the lower part of the horizon in the Kopina 1 borehole (samples K2, K3 and K4). 

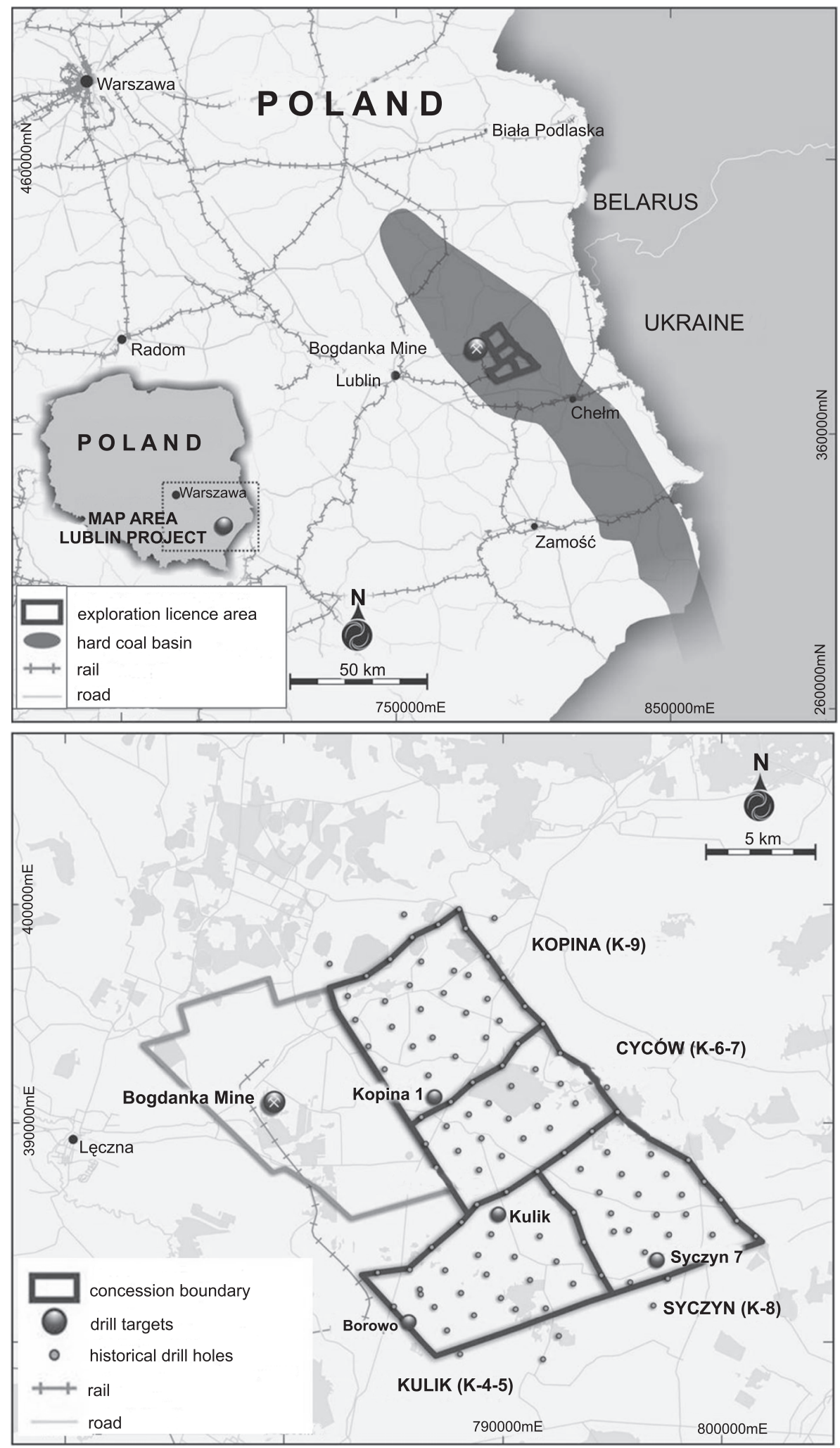

Fig. 3. Location of the sampled boreholes: Kopina 1, Kulik, Borowo, Syczyn 7 carried out under the Lublin Coal Project (http://www.pdz.com.au)

Degree of pyritization (DOP) is often applied to determine the palaeoredox conditions (Hatch and Leventhal, 1992; Cruse and Lyons, 2000; Rimmer, 2004; Algeo and Maynard, 2008). DOP is defined as the pyrite iron/pyrite iron + reactive iron (\% $\left.\mathrm{Fe}_{\text {pyrite }} / \% \mathrm{Fe}_{\text {pyrite }}{ }_{\text {reactive }} \mathrm{Fe}\right)($ Berner, 1970$)$ ratio. Raiswell et al. (1988) have suggested that sediments with DOP less than 0.46 indicate aerobic conditions, DOP values between 0.46 and 0.75 indicate dysoxic or restricted conditions, and DOP values $>0.75$ suggest anoxic (inhospitable) conditions for the sediment deposition. 


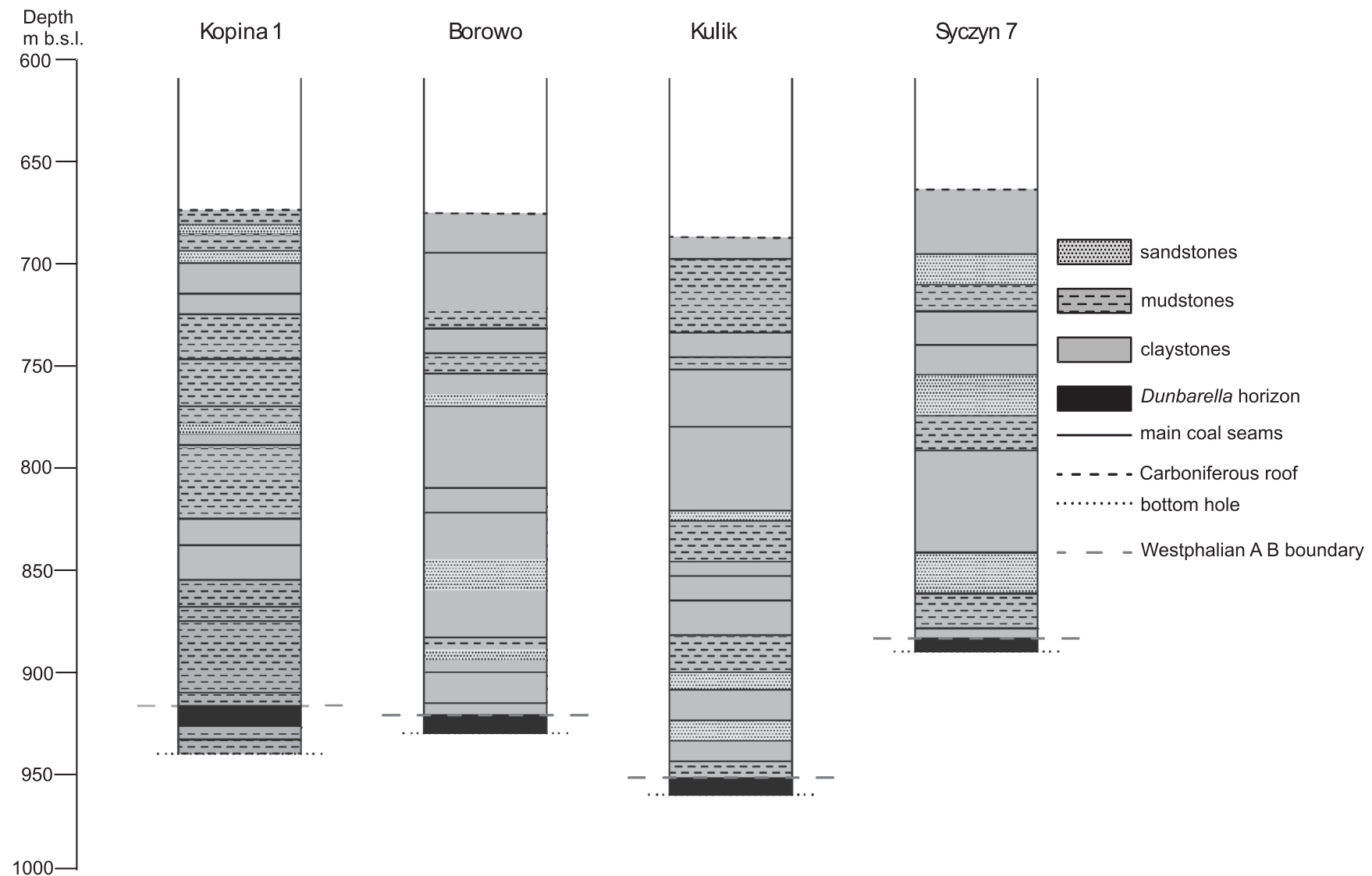

Fig. 4. Location of the Dunbarella horizon within the simplified Carboniferous profiles of the Kopina 1, Borowo, Kulik and Syczyn 7 boreholes (LCB) (after Krzeszowska and Kokowska-Pawłowska, 2017: fig. 2 ibidem, simplified)

Calculation of DOP values requires determination of reactive iron, but Algeo and Maynard $(2004,2008)$ proposed making a rough assessment using $\mathrm{DOP}_{\mathrm{t}}$ values (in place of true $\mathrm{DOP}$ ). $\mathrm{DOP}_{\mathrm{t}}$ is based on the ratio of pyrite $\mathrm{Fe}$ (based on total $\mathrm{S})$ to total $\mathrm{Fe}$. This index can be used in place of true DOP, if pyrite $\mathrm{S}$ composes the bulk of total $\mathrm{S}$, and reactive $\mathrm{Fe}$ composes the bulk of total Fe (Algeo and Maynard, 2008). Although $\mathrm{DOP}_{\mathrm{t}}$ values are systematically lower than true DOP values, there is a strong relationship between the two parameters, and $\mathrm{DOP}_{\mathrm{t}}$ can be used as an estimator of true DOP (Algeo and Maynard, 2008).

$\mathrm{DOP}_{\mathrm{t}}$ values for aerobic conditions are typically $<0.3$ for restricted conditions between 0.3 and 0.6 , while for inhospitable conditions it is usually $>0.6$ (Algeo and Maynard, 2008).

In this study, $\mathrm{DOP}_{\mathrm{t}}$ values (in place of true DOP) have been analysed. $\mathrm{DOP}_{\mathrm{t}}$ values for most of the samples are low indicating aerobic or restricted conditions (Fig. 7 and Table 1). The samples from the lower part of the horizon in the Kopina 1 borehole $(\mathrm{K} 2, \mathrm{~K} 3, \mathrm{~K} 4)$ show higher $\mathrm{DOP}_{\mathrm{t}}$ values which indicate anoxic conditions.

\section{REDOX-SENSITIVE TRACE ELEMENT}

Redox-sensitive trace element (TEs) concentrations (such as $\mathrm{U}, \mathrm{V}, \mathrm{Mo}, \mathrm{Cr}, \mathrm{Co}, \mathrm{Ni}, \mathrm{Cu}, \mathrm{Zn}$ and $\mathrm{Pb}$ ) have been frequently used as indicators of redox conditions in modern and ancient sedimentary systems (e.g., Calvert and Pedersen, 1993; Jones and Manning, 1994; Wignall, 1994; Algeo, 2004; Rimmer, 2004; Tribovillard et al., 2006; Algeo and Maynard, 2008; Pearce et al., 2010; Racki et al., 2012; Wójcik-Tabol, 2015). The most useful trace elements for palaeoenvironmental analyses are $U$ and Mo, because they:

- demonstrate conservative behaviour under oxic conditions and have long residence times in seawater,

- exhibit nearly consistent concentrations in seawater globally,

- are present in low concentrations in plankton, so enrichments in sediments generally comes from seawater, especially under oxygen-depleted conditions (Algeo and Tribovillard, 2009).

TEs commonly exhibit considerable enrichment in laminated, organic-rich facies, especially those deposited under euxinic conditions (Algeo and Maynard, 2008). On the other hand, inferences regarding palaeoenvironmental conditions based on trace element concentrations are commonly unreliable if single element distributions are used, because their concentrations are influenced by many factors and mechanisms (Tribovillard et al., 2006). Many authors consider not only the concentration of elements but also the degree of enrichment or depletion of a trace element to reconstruct palaeoenvironmental conditions (e.g., Wedepohl, 1991; Rimmer, 2004; Brumsack, 2006; Tribovillard et al., 2006; Kombrink, 2008; Algeo and Tribovillard, 2009). The method of geochemical normalization and calculation of enrichment factors (EFs) is as follows: 

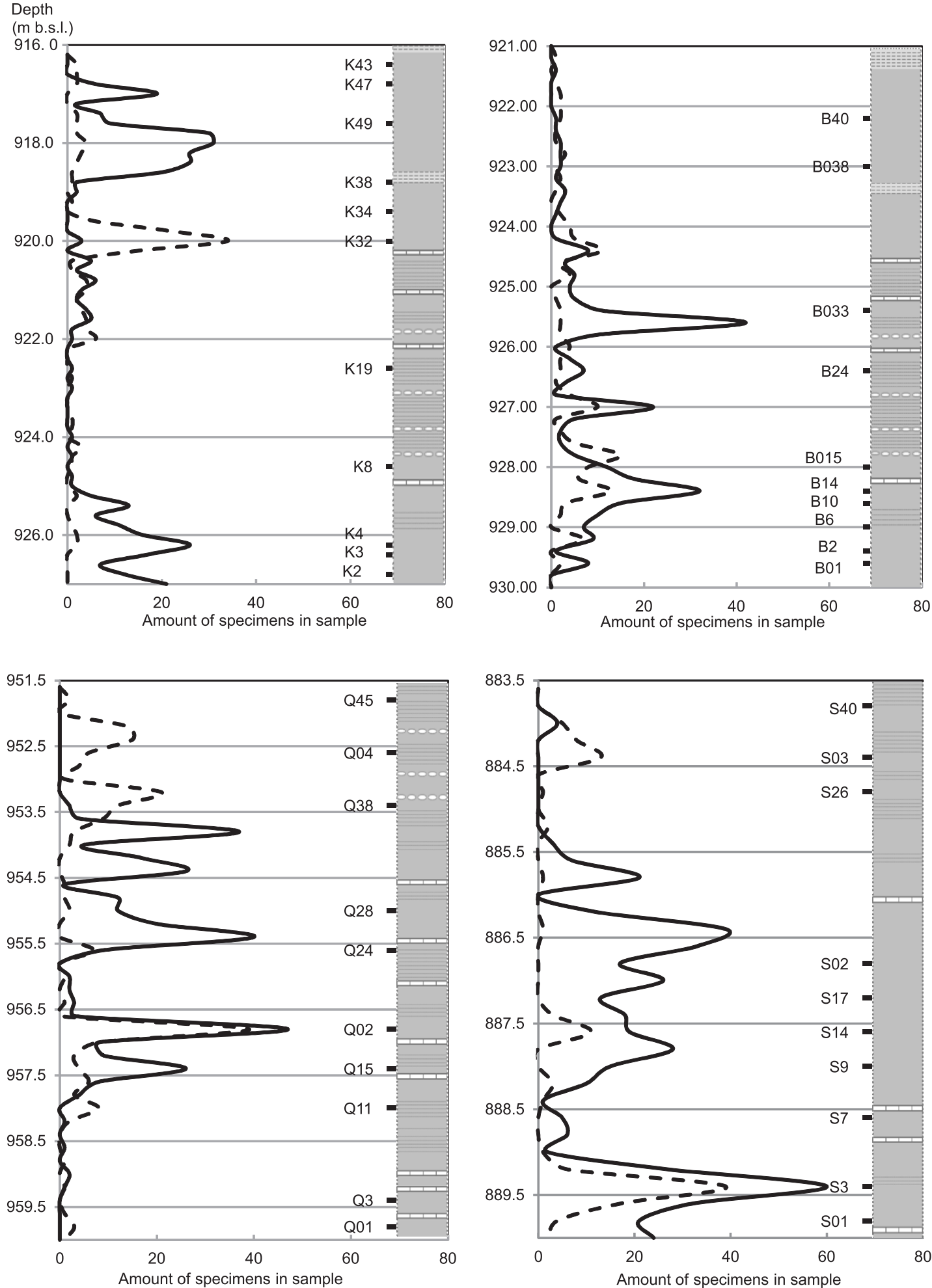

— Molusca (mainly Bivalvia)

- - Brachiopoda (mainly Lingula)

S3 sampling locations

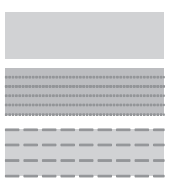

claystones

carbonate inerlayers

sandy claystones

mudstones

Fig. 5. Mollusc/brachiopod dynamics and sampling location within the Dunbarella marine marker horizon (LCB)

A - Kopina 1, B - Borowo, C - Kulik, D - Syczyn 7; after Krzeszowska (2015: fig. 5 ibidem) 

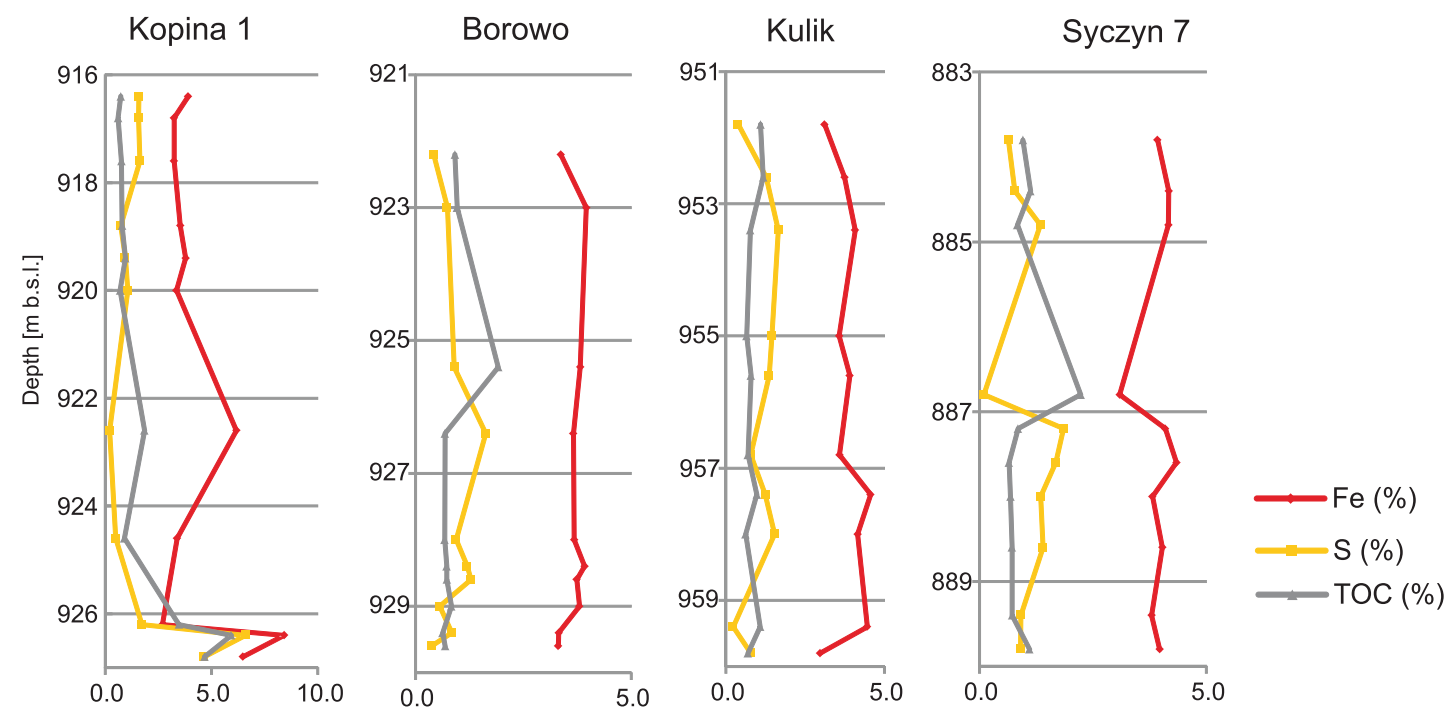

Fig. 6. Vertical distribution of TOC, S and Fe within the Dunbarella marine horizon in the Lublin Coal Basin

Table 1

Major palaeontological and geochemical data for samples from the Dunbarella horizon

\begin{tabular}{|c|c|c|c|c|c|c|c|c|c|c|c|c|c|c|}
\hline \multirow{3}{*}{$\begin{array}{l}\text { Bore- } \\
\text { hole }\end{array}$} & \multirow{3}{*}{ Sample } & \multirow{3}{*}{$\begin{array}{c}\text { Depth } \\
\text { (m b.s.I.) }\end{array}$} & \multicolumn{2}{|c|}{ Major palaeontological data } & \multicolumn{10}{|c|}{ Major geochemical proxies } \\
\hline & & & \multirow{2}{*}{$\begin{array}{c}\text { Genus } \\
\text { dominated }\end{array}$} & \multirow{2}{*}{$\begin{array}{c}\text { Main genus } \\
\text { accompanying }\end{array}$} & TOC & $\mathrm{S}$ & $\mathrm{Fe}$ & \multirow{2}{*}{$\mathrm{DOP}_{\mathrm{t}}$} & \multirow{2}{*}{$\mathrm{U}_{\text {aut }}$} & \multirow{2}{*}{$E F_{U}$} & \multirow{2}{*}{ EFmo } & \multirow{2}{*}{$\mathrm{V} / \mathrm{Cr}$} & \multirow{2}{*}{$\mathrm{Ni} / \mathrm{Co}$} & \multirow{2}{*}{$\mathrm{V} /(\mathrm{Ni}=\mathrm{V})$} \\
\hline & & & & & $\%$ & $\%$ & $\%$ & & & & & & & \\
\hline \multirow{11}{*}{ 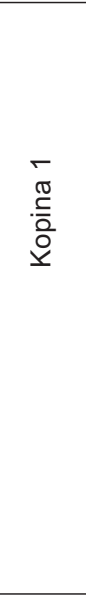 } & K43 & 916.4 & No & fauna & \multirow{6}{*}{$<1$} & 1.58 & 3.90 & 0.41 & 0.00 & 1.51 & 0.95 & \multirow{11}{*}{$<2$} & \multirow{8}{*}{$<5$} & \multirow{11}{*}{$0.58-0.67$} \\
\hline & K47 & 916.8 & $\begin{array}{c}\text { Edmondia } \\
\text { Sanguinolites }\end{array}$ & Lingula & & 1.56 & 3.24 & 0.48 & & 1.73 & 1.10 & & & \\
\hline & K49 & 917.6 & Posidonia & $\begin{array}{c}\text { Edmondia } \\
\text { Sanguinolites } \\
\text { Dunbarella } \\
\text { Anthracoceras }\end{array}$ & & 1.63 & 3.24 & 0.50 & 0.27 & 1.88 & 1.24 & & & \\
\hline & K38 & 918.8 & \multicolumn{2}{|c|}{ Remains of freshwater fauna } & & 0.72 & 3.53 & 0.20 & \multirow{5}{*}{0.00} & 1.40 & 0.23 & & & \\
\hline & K34 & 919.4 & \multicolumn{2}{|c|}{ No fauna } & & 0.94 & 3.78 & 0.25 & & 1.41 & 0.17 & & & \\
\hline & K32 & 920.0 & & gula & & 1.05 & 3.35 & 0.31 & & 1.39 & 0.21 & & & \\
\hline & K19 & 922.6 & \multirow{2}{*}{\multicolumn{2}{|c|}{ No fauna }} & 1.84 & 0.20 & 6.17 & 0.03 & & 1.11 & 0.58 & & & \\
\hline & $\mathrm{K} 8$ & 924.6 & & & $<1$ & 0.48 & 3.38 & 0.14 & & 1.12 & 0.32 & & & \\
\hline & K4 & 926.2 & \multirow{2}{*}{$\begin{array}{l}\text { Posidonia } \\
\text { Euchondria } \\
\text { Dunbarella }\end{array}$} & \multirow{2}{*}{$\begin{array}{c}\text { Dunbarella } \\
\text { Anthracoceras } \\
\text { Gastrioceras }\end{array}$} & 3.46 & 1.72 & 2.69 & 0.64 & 5.60 & 2.76 & 20.93 & & 6.74 & \\
\hline & K3 & 926.4 & & & 5.93 & 6.60 & 8.42 & 0.78 & 1.87 & 1.88 & 2.37 & & \multirow[b]{2}{*}{$<5$} & \\
\hline & K2 & 926.8 & $\begin{array}{l}\text { Carbonicola } \\
\text { Naiadites }\end{array}$ & $\begin{array}{c}\text { Curvirimula } \\
\text { Anthracosia }\end{array}$ & 4.67 & 4.65 & 6.47 & 0.72 & 1.20 & 1.57 & 1.81 & & & \\
\hline \multirow{10}{*}{ 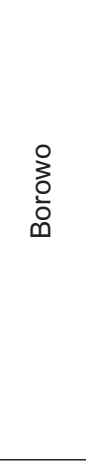 } & B40 & 922.2 & \multicolumn{2}{|c|}{ Remains of freshwater fauna } & $<1$ & 0.42 & 3.37 & 0.12 & 0.57 & 1.40 & 0.32 & \multirow{10}{*}{$<2$} & \multirow{10}{*}{$<5$} & \\
\hline & B038 & 923.0 & No & fauna & 0.74 & 3.96 & 0.19 & 0.60 & 1.41 & 0.40 & & & & \\
\hline & B033 & 925.4 & $\begin{array}{c}\text { Edmondia } \\
\text { Sanguinolites }\end{array}$ & $\begin{array}{c}\text { Posidonia } \\
\text { Anthracoceras }\end{array}$ & 1.92 & 0.90 & 3.82 & 0.24 & 0.38 & 1.57 & 0.49 & & & \\
\hline & B24 & 926.4 & Posidonia & $\begin{array}{c}\text { Edmondia } \\
\text { Sanguinolites }\end{array}$ & & 1.63 & 3.66 & 0.45 & 0.00 & 1.43 & 0.43 & & & \\
\hline & B015 & 928.0 & Lingula & Posidonia & & 0.94 & 3.68 & 0.26 & 0.27 & 1.66 & 0.32 & & & $0.60-0.69$ \\
\hline & B14 & 928.4 & & & & 1.20 & 3.92 & 0.31 & 0.03 & 1.39 & 1.43 & & & \\
\hline & B10 & 928.6 & & & $<1$ & 1.29 & 3.74 & 0.34 & & 1.22 & 0.29 & & & \\
\hline & $\mathrm{B} 6$ & 929.0 & $\begin{array}{c}\text { Posidonia } \\
\text { Dunbarella }\end{array}$ & $\begin{array}{c}\text { Polidevcia } \\
\text { Anthracoceras }\end{array}$ & & 0.56 & 3.80 & 0.15 & & 1.14 & 0.35 & & & \\
\hline & $\mathrm{B} 2$ & 929.4 & & & & 0.84 & 3.32 & 0.25 & 0.00 & 1.17 & 0.27 & & & \\
\hline & B01 & 929.6 & & & & 0.37 & 3.31 & 0.11 & & 1.34 & 0.43 & & & \\
\hline
\end{tabular}


Tab. 1 cont

\begin{tabular}{|c|c|c|c|c|c|c|c|c|c|c|c|c|c|c|}
\hline \multirow{3}{*}{$\begin{array}{l}\text { Bore- } \\
\text { hole }\end{array}$} & \multirow{3}{*}{ Sample } & \multirow{3}{*}{$\begin{array}{l}\text { Depth } \\
\text { (m b.s.l.) }\end{array}$} & \multicolumn{2}{|c|}{ Major palaeontological data } & \multicolumn{10}{|c|}{ Major geochemical proxies } \\
\hline & & & \multirow{2}{*}{$\begin{array}{c}\text { Genus } \\
\text { dominated }\end{array}$} & \multirow{2}{*}{$\begin{array}{l}\text { Main genus } \\
\text { accompanying }\end{array}$} & TOC & $\mathrm{S}$ & $\mathrm{Fe}$ & \multirow[b]{2}{*}{$\mathrm{DOP}_{\mathrm{t}}$} & \multirow{2}{*}{$U_{\text {aut }}$} & \multirow{2}{*}{$\mathrm{EF}_{U}$} & \multirow{2}{*}{$\mathrm{EF}_{\mathrm{Mo}}$} & \multirow{2}{*}{$\mathrm{V} / \mathrm{Cr}$} & \multirow{2}{*}{$\mathrm{Ni} / \mathrm{Co}$} & \multirow{2}{*}{$\mathrm{V} /(\mathrm{Ni}=\mathrm{V})$} \\
\hline & & & & & $\%$ & $\%$ & $\%$ & & & & & & & \\
\hline \multirow{10}{*}{ 旁 } & Q45 & 951.8 & Remains of fre & shwater fauna & 1.09 & 0.39 & 3.11 & 0.13 & 0.53 & 1.56 & 0.34 & \multirow{10}{*}{$<2$} & \multirow{10}{*}{$<5$} & \multirow{10}{*}{$0.57-0.70$} \\
\hline & Q04 & 952.6 & Lin & gula & 1.17 & 1.27 & 3.74 & 0.34 & 0.00 & 1.30 & 0.40 & & & \\
\hline & Q38 & 953.4 & Lin & gula & \multirow{6}{*}{$<1$} & 1.65 & 4.07 & 0.41 & 0.27 & 1.62 & 0.76 & & & \\
\hline & Q28 & 955.0 & \multirow[b]{2}{*}{ Edmondia } & \multirow{2}{*}{$\begin{array}{c}\text { Posidonia } \\
\text { Dunbarella } \\
\text { Sanguinolites } \\
\text { Anthracoceras } \\
\text { Lingula }\end{array}$} & & 1.45 & 3.57 & 0.41 & \multirow{7}{*}{0.00} & 1.46 & 0.61 & & & \\
\hline & Q24 & 955.6 & & & & 1.36 & 3.90 & 0.35 & & 1.50 & 0.63 & & & \\
\hline & Q02 & 956.8 & $\begin{array}{l}\text { Polidevcia, } \\
\text { Phestia } \\
\text { Lingula }\end{array}$ & $\begin{array}{c}\text { Posidonia } \\
\text { Dunbarella } \\
\text { Anthracoceras }\end{array}$ & & 0.78 & 3.58 & 0.22 & & 1.35 & 1.07 & & & \\
\hline & Q15 & 957.4 & $\begin{array}{l}\text { Polidevcia, } \\
\text { Phestia }\end{array}$ & $\begin{array}{c}\text { Posidonia } \\
\text { Dunbarella } \\
\text { Anthracocera } \\
\text { Lingula } \\
\text { Edmondia }\end{array}$ & & 1.24 & 4.56 & 0.27 & & 1.59 & 3.29 & & & \\
\hline & Q11 & 958.0 & \multicolumn{2}{|c|}{ Lingula } & & 1.53 & 4.15 & 0.37 & & 1.19 & 0.35 & & & \\
\hline & Q3 & 959.4 & \multicolumn{2}{|c|}{ No fauna } & 1.08 & 0.23 & 4.45 & 0.05 & & 1.14 & 0.21 & & & \\
\hline & Q01 & 959.8 & \multicolumn{2}{|c|}{ Few faunal specimens - Lingula } & $<1$ & 0.78 & 2.97 & 0.26 & & 1.09 & 0.49 & & & \\
\hline \multirow{10}{*}{ 代 } & $\mathrm{S} 40$ & 883.8 & \multicolumn{2}{|c|}{ Remains of freshwater fauna } & $<1$ & 0.64 & 3.92 & 0.16 & 0.60 & 1.47 & 0.28 & \multirow{10}{*}{$<2$} & & \\
\hline & S03 & 884.4 & \multicolumn{2}{|c|}{ Lingula } & 1.12 & 0.78 & 4.17 & 0.19 & 0.10 & 1.51 & 0.53 & & & \\
\hline & S26 & 884.8 & \multicolumn{2}{|c|}{ No fauna } & $<1$ & 1.34 & 4.16 & 0.32 & 0.67 & 1.57 & 0.56 & & & \\
\hline & S02 & 886.8 & \begin{tabular}{|l|} 
Dunbarella \\
Posidonia
\end{tabular} & $\begin{array}{c}\text { Edmondia } \\
\text { Sanguinolites }\end{array}$ & 2.23 & 0.10 & 3.09 & 0.03 & 1.20 & 2.33 & 0.35 & & & \\
\hline & S17 & 887.2 & $\begin{array}{l}\text { Dunbarella } \\
\text { Posidonia }\end{array}$ & Anthracoceras & & 1.85 & 4.09 & 0.45 & 0.00 & 1.59 & 1.31 & & & \\
\hline & S14 & 887.6 & & Dunbarella & & 1.68 & 4.34 & 0.39 & 0.07 & 1.54 & 1.04 & & $<5$ & \\
\hline & s9 & 888.0 & Sanguinolites & $\begin{array}{c}\text { Anthracoceras } \\
\text { Lingula }\end{array}$ & & 1.35 & 3.81 & 0.35 & 0.00 & 1.30 & 0.36 & & $<5$ & $0.59-0.73$ \\
\hline & S7 & 888.6 & Posidonia & $\begin{array}{c}\text { Phestia } \\
\text { Dunbarella }\end{array}$ & $<1$ & 1.40 & 4.03 & 0.35 & & 1.42 & 0.51 & & & \\
\hline & S3 & 889.4 & $\begin{array}{l}\text { Posidonia } \\
\text { Phestia }\end{array}$ & $\begin{array}{c}\text { Dunbarella } \\
\text { Anthracoceras } \\
\text { Lingula }\end{array}$ & & 0.91 & 3.79 & 0.24 & 0.03 & 1.50 & 0.49 & & & \\
\hline & S01 & 889.8 & $\begin{array}{c}\text { Posidonia } \\
\text { Phestia } \\
\text { Dunbarella } \\
\end{array}$ & $\begin{array}{c}\text { Anthracoceras } \\
\text { Gastrioceras }\end{array}$ & 1.10 & 0.90 & 3.97 & 0.23 & 0.00 & 1.51 & 0.70 & & & \\
\hline
\end{tabular}
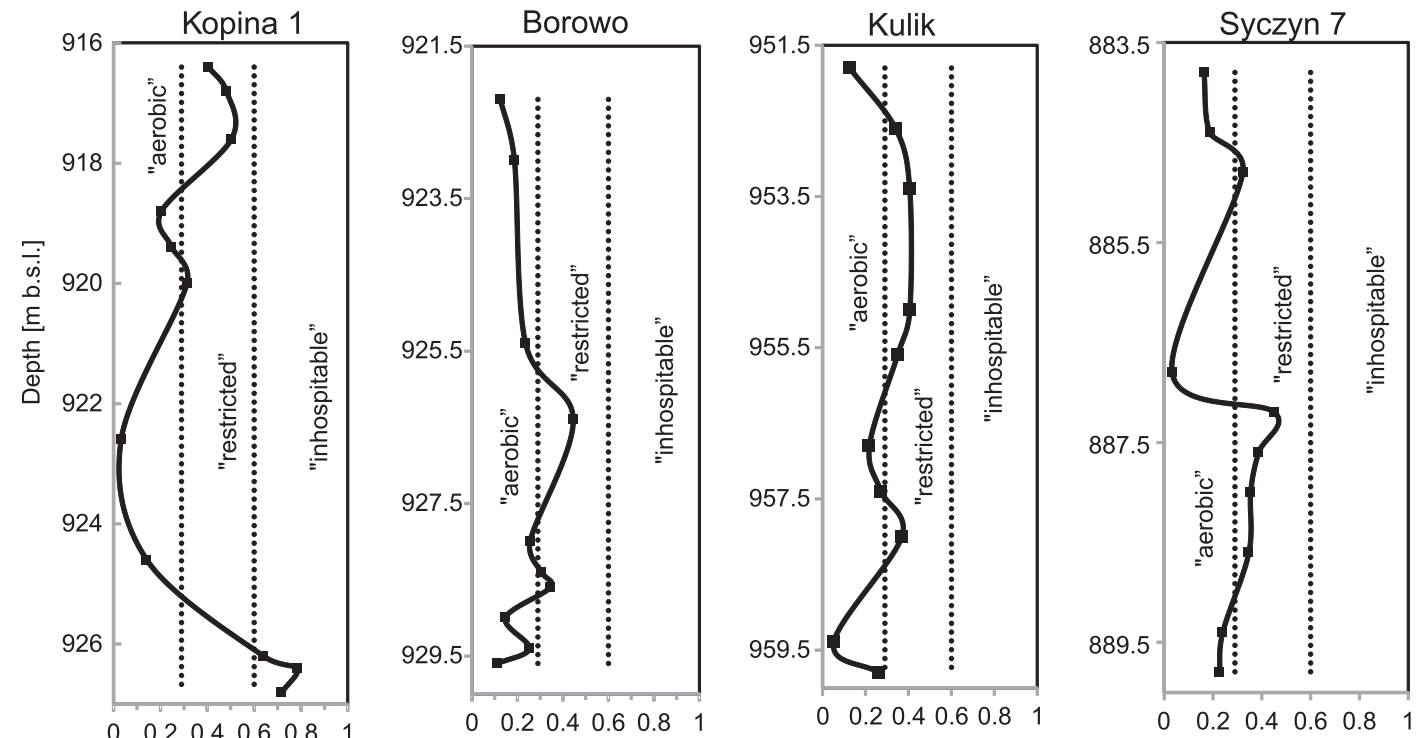

$-\mathrm{DOP}_{\mathrm{t}}$

Fig. 7. Vertical variability of the estimate of degree of pyritization $\left(D_{0} P_{t}\right)$ within the Dunbarella marine horizon. The boundaries for aerobic, restricted and inhospitable conditions (based on DOP $P_{t}$ )

were established according to Algeo et al. (2008) 


$$
E F=\frac{\frac{\mathrm{El}_{\mathrm{s}}}{\mathrm{Al}}}{\frac{\mathrm{El}_{\mathrm{av}}}{\mathrm{Al}_{\mathrm{av}}}}
$$

where: $\mathrm{El}_{\mathrm{s}}$ - element concentration in the sample, $\mathrm{Al}_{\mathrm{s}}-\mathrm{Al}$ concentration in the sample, $\mathrm{El}_{\mathrm{av}}$ - element concentration in average crustal rocks or average shale, and $\mathrm{Al}_{\mathrm{av}}-\mathrm{Al}$ concentration in average crustal rocks or average shale.

$\mathrm{U}$ is the most important redox-sensitive trace element for reconstruction of the sedimentary environment (e.g., Leeder, 1988; Fisher and Wignall, 2001; Rimmer, 2004; Kombrink, 2008; Algeo and Tribovillard, 2009; Pearce et al., 2010; Wójcik-Tabol, 2015). The $U$ content of sediments is a combination of authigenic and detrital components, and authigenic $U$ is a suitable indicator of redox conditions (Jones and Manning, 1994). Authigenic uranium can be calculated as $\cup_{\text {aut }}=$ $\mathrm{U}_{\text {tot }}-\mathrm{Th} / 3$, with $\mathrm{Th} / 3$ as an estimate of the detrital uranium fraction in mudstones (Wignall and Myers, 1988). Reducing conditions may precipitate uranium to enrich the sediment in authigenic (non-detrital) uranium. Its values $<5$ indicate oxic conditions, while values $5-12$ and $>12$ indicate dysoxic and suboxic to anoxic conditions, respectively (Jones and Manning, 1994). Algeo and Tribovillard (2009) proposed to use enrichment factors (EF) for rapid assessment of the authigenic fraction of $U$ (similarly for Mo), indicating that the detectable authigenic enrichment corresponds to EF>3, and the substantial enrichment to $E F>10$.

The $U$ contents of the samples from the Dunbarella marine horizon range from 3.5 to 11.6 ppm (Fig. 8 and Appendix 1). Only three samples showed values $>6 \mathrm{ppm}$, which suggest marine deposition under reducing conditions (Leeder et al., 1990; samples from the lower part of the horizon in the Kopina 1 borehole and from the middle part of the horizon in the Syczyn 7 borehole). Most of the samples have low $E_{U}$ values, calculated relative to average shale (Wedepohl, 1991) (1.09-2.76), and the lack of authigenic $U$. This indicates oxic sedimentary environment (Fig. 8, Table 1 and Appendix 2).
Mo concentration, which (next to $U$ ) has been reported as the most important indicator in distinguishing oxic, suboxic and anoxic facies (Algeo and Lyons, 2006; Algeo and Rowe, 2012; Marynowski et al., 2017), shows significant variability in the samples from the Dunbarella horizon. The $\mathrm{EF}_{\mathrm{Mo}}$ values range from 0.17 to 20.93 (Table 1), but high Mo concentrations were observed only in the samples from the lower part of the horizon in the Kopina 1 borehole (samples $\mathrm{K} 2$, K3 and K4) and from the middle part of the horizon in the Kulik borehole (sample Q15), suggesting oxygen-depleted sedimentary facies.

Algeo and Tribovillard (2009) analysed patterns of covariation between Mo and $U$ in modern and ancient anoxic marine systems. To compare enrichments of these elements, they proposed using enrichment factors $\left(\mathrm{EF}_{\mathrm{Mo}}, \mathrm{EF}_{\mathrm{U}}\right)$ that are useful for rapid assessment of the authigenic fraction of Mo and $\mathrm{U}$. Algeo and Tribovillard (2009) stated that $\mathrm{EF}_{\mathrm{Mo}}$ versus $\mathrm{EF}_{\mathrm{U}}$ crossplots (Fig. 9), in which the Mo/U molar ratio ( 7.5-7.9) of seawater is a guide to interpreting relative enrichments of Moauth versus Uauth, can be applied for palaeoenvironmental analyses. Oxic facies show little or no Mo and $U$ enrichments, suboxic facies exhibit modest enrichment with $\mathrm{Mo}_{\text {aut }} / \mathrm{U}_{\text {aut. }}$ (clearly lower than the seawater ratio), while anoxic facies exhibit strong enrichment accompanied by progressively higher $\mathrm{Mo}_{\text {aut }} / \mathrm{U}_{\text {aut. }}$ ratios (Algeo and Tribovillard, 2009).

Most of the samples from the Dunbarella horizon show low $\mathrm{U}_{\text {aut }}$ enrichment and lack of $\mathrm{Mo}_{\text {aut }}$ enrichment, corresponding to the seawater Mo/ $U$ molar ratio of $<0.2$, indicating oxic conditions (Fig. 9 and Appendix 2). Samples showing low $U_{\text {aut. }}$ and $\mathrm{Mo}_{\text {aut. }}$ enrichments $\left(E F_{U}\right.$ and $E F_{M o}$ between 1-3) yielding seawater Mo/U molar ratio of $\sim 0.2-0.7$, suggest variable redox conditions, probably ranging from oxic or suboxic. Only one sample (from the lower part of the horizon in the Kopina 1) has distinctly higher $\mathrm{Mo}_{\text {aut. }}$ enrichment and moderate $\mathrm{U}_{\text {aut. }}$ enrichment, representing the Mo/U molar ratio greater than that of seawater, which strongly suggests anoxic facies.

In addition to $U$ and Mo, other redox-sensitive trace metals can be useful as palaeoredox proxies. $\mathrm{V}, \mathrm{Cr}$ and $\mathrm{Co}$ tend to be more soluble under oxidizing conditions and less soluble under reducing conditions, resulting in authigenic enrichments in oxy-
Kopina 1

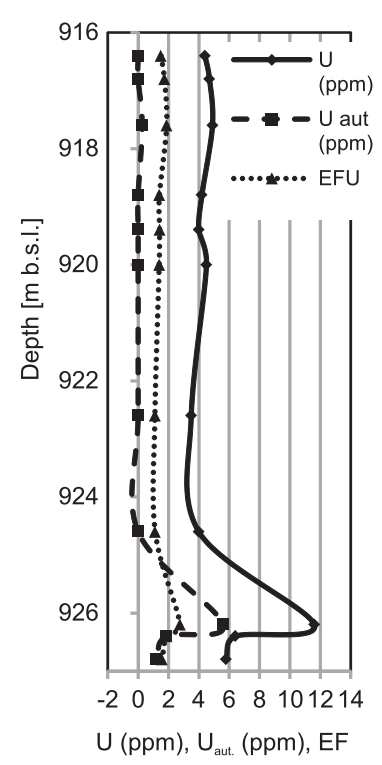

Borowo

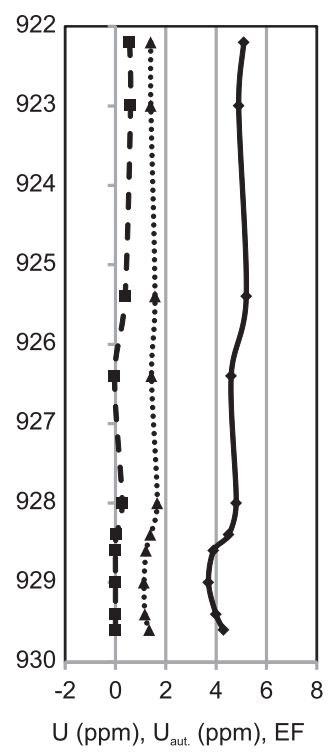

Kulik

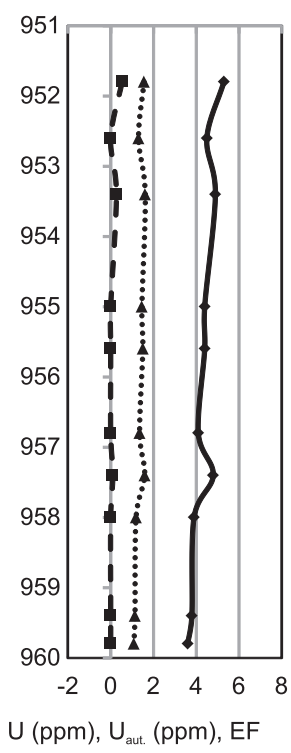

Syczyn 7

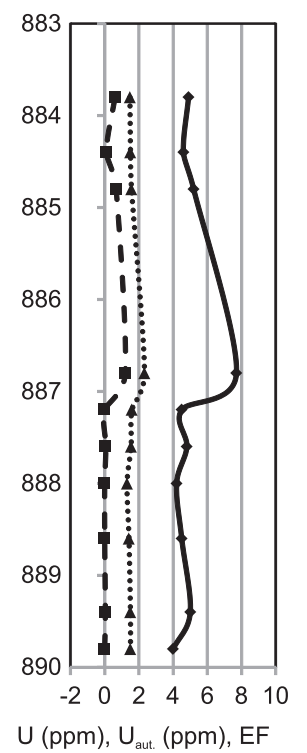

Fig. 8. Vertical distribution of uranium in the Dunbarella marine horizon 


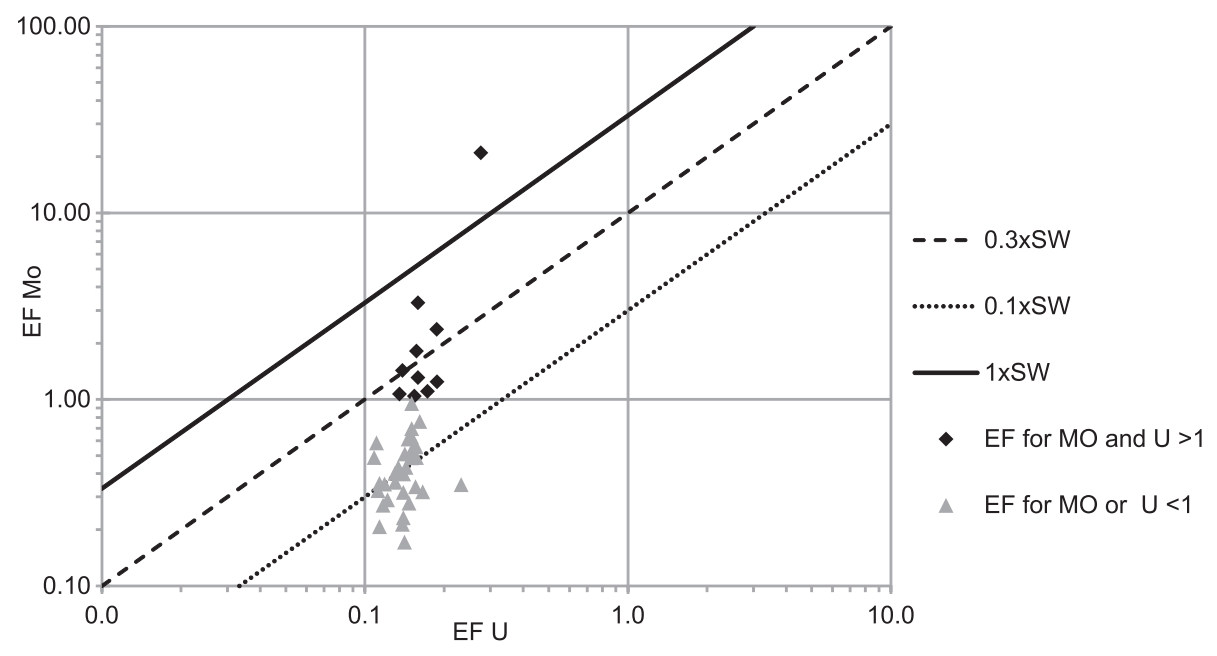

Fig. 9. Crossplot of enrichment factors EFMo vs $E_{U}$ for samples from the Dunbarella horizon (LCB)

The lines show Mo/U molar ratios equal to the seawater value $(1 \times \mathrm{SW})$ and to fractions thereof $0.3 \times$ SW and $0.1 \times$ SW by Algeo and Tribovillard (2009)

gen-depleted sedimentary facies (Tribovillard et al., 2006). All the redox-sensitive trace elements examined in this study (except for Mo) exhibited low EFs (calculated relative to average shale - Wedepohl, 1991) varying from 0.38 to 3.01 , with the mean values for the elements ranging from 0.87 to 1.77 (Fig. 10 and Appendix 1).

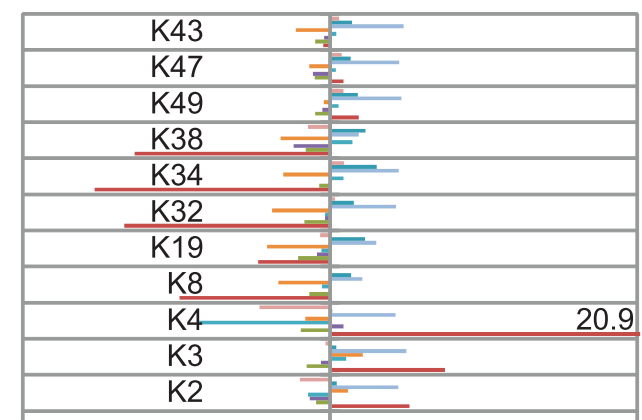

0.1

EF 1

100.1

\begin{tabular}{|c|}
\hline S40 \\
\hline S03 \\
\hline S26 \\
\hline S02 \\
\hline S17 \\
\hline S14 \\
\hline S9 \\
\hline S7 \\
\hline S3 \\
\hline S01 \\
\hline
\end{tabular}

0.1

1

EF

\section{TRACE ELEMENT INDICES}

$\mathrm{V} / \mathrm{Cr}, \mathrm{Ni} / \mathrm{Co}$ and $\mathrm{V} /(\mathrm{V}+\mathrm{Ni})$ trace element indices have been suggested to evaluate palaeoredox conditions in many studies (e.g., Dill et al., 1988; Hatch and Leventhal, 1992; Jones and Manning, 1994; Rimmer, 2004; Algeo and Maynard, 2008;

\begin{tabular}{|c|}
\hline $\mathrm{B} 40$ \\
\hline $\mathrm{B} 038$ \\
\hline $\mathrm{B} 033$ \\
\hline $\mathrm{B} 24$ \\
\hline $\mathrm{B} 015$ \\
\hline $\mathrm{B} 14$ \\
\hline $\mathrm{B} 10$ \\
\hline $\mathrm{B} 6$ \\
\hline $\mathrm{B} 2$ \\
\hline $\mathrm{B} 01$ \\
\hline
\end{tabular}

EF $^{1}$

10

\begin{tabular}{|c|}
\hline Q45 \\
\hline Q04 \\
\hline Q38 \\
\hline Q28 \\
\hline Q24 \\
\hline Q02 \\
\hline Q15 \\
\hline Q11 \\
\hline Q3 \\
\hline Q01 \\
\hline
\end{tabular}

100.1

$\mathrm{EF}^{1}$

$\approx \mathrm{Co} \backsim \mathrm{Cr} \backsim \mathrm{Pb} \backsim \mathrm{Cu} \backsim \mathrm{Zn} \backsim \mathrm{Ni} \backsim \mathrm{V} \backsim \mathrm{Mo}$

Fig. 10. Enrichment factors (EF) for samples from the Dunbarella horizon of the LCB 
Racka et al., 2010; Marynowski et al., 2012; Racki et al., 2012; Wójcik-Tabol, 2015). Jones and Manning (1994) proposed to use $\mathrm{V} / \mathrm{Cr}$ ratios to estimate the palaeoredox depositional conditions, with $\mathrm{V} / \mathrm{Cr}<2$ indicating oxidizing condition, $2<$ $\mathrm{V} / \mathrm{Cr}<4.25$ indicating a dysoxic sedimentary environment, and $\mathrm{V} / \mathrm{Cr}>4.25$ indicating a reducing environment. The $\mathrm{Ni} / \mathrm{Co}$ ratios $<5$ indicate oxic environments, Ni/Co ratios between 5 and 7 suggest dysoxic environments, while higher ratios ( $\mathrm{Ni} / \mathrm{Co}$ $>7$ ) suggest anoxic conditions (Jones and Manning, 1994; Rimmer, 2004). Hatch and Leventhal (1992) used V/(V + Ni) ratios as a parameter distinguishing oxic and anoxic bottom waters by suggesting that a high $\mathrm{V} /(\mathrm{V}+\mathrm{Ni})$ ratio $(>0.84)$ indicates the presence of $\mathrm{H}_{2} \mathrm{~S}$ in the water column (euxinic conditions), a ratio between 0.46 to 0.84 represents anoxic to dysoxic conditions, and a ratio $<0.46$ represents oxic conditions.

The $\mathrm{V} / \mathrm{Cr}$ ratios in samples from the Dunbarella horizon are generally uniform and relatively low (0.9-1.4), suggesting oxic environments, while $\mathrm{Ni} / \mathrm{Co}$ ratios varying from 2.6 to 6.7 for a sample from the lower part of the horizon in the Kopina 1 borehole (sample K4) indicate dysoxic environments (Fig. 11). V/(V+ Ni) ratios for all studied samples range between 0.57 and 0.73 , which suggests dysoxic to anoxic conditions that do not correspond with the other trace element indicators analysed above (Fig. 12). Similar results were reported, inter alia, for the Devonian-Mississippian black shales (Rimmer, 2004; Rimmer et al., 2004), Middle Jurassic mudstones (Szczepanik et al., 2007; Zatoń et al., 2009), and Upper Famennian of the Holy Cross Mountains (Racka et al., 2010), since the V/(V + $\mathrm{Ni}$ ) ratios predicted lower oxygen conditions than either $\mathrm{Ni} / \mathrm{Co}$ or $\mathrm{V} / \mathrm{Cr}$.

\section{GEOCHEMICAL PROXIES VS. PALAEONTOLOGICAL RECORD}

Detailed palaeontological study of the Dunbarella faunal horizon in the Lublin Coal Basin (Poland) has shown the presence of abundant macrofauna - mostly molluscs, brachiopods, and some representatives of crinoids, arthropods and fish (Krzeszowska, 2015). The distribution of fauna in the analysed horizon within the investigated boreholes fluctuates in terms of both abundance and taxonomy, and cyclic sedimentation typical of marine Westphalian horizons was observed.

Palaeontological study of the Dunbarella showed the presence of intervals with a different palaeontological record. The samples studied represent deposits containing:

- typical marine fauna (e.g., Dunbarella, Posidonia, Anthracoceras, Gastrioceras), occasionally accompanied by bivalve taxa of high salinity tolerance (Edmondia, Sanguinolites),

- brackish or high salinity-tolerant faunas (Lingula, Edmondia, Sanguinolites),

- freshwater fauna (e.g., Carbonicola, Naiadites) or indeterminate remains,

- no fauna (Table 1).

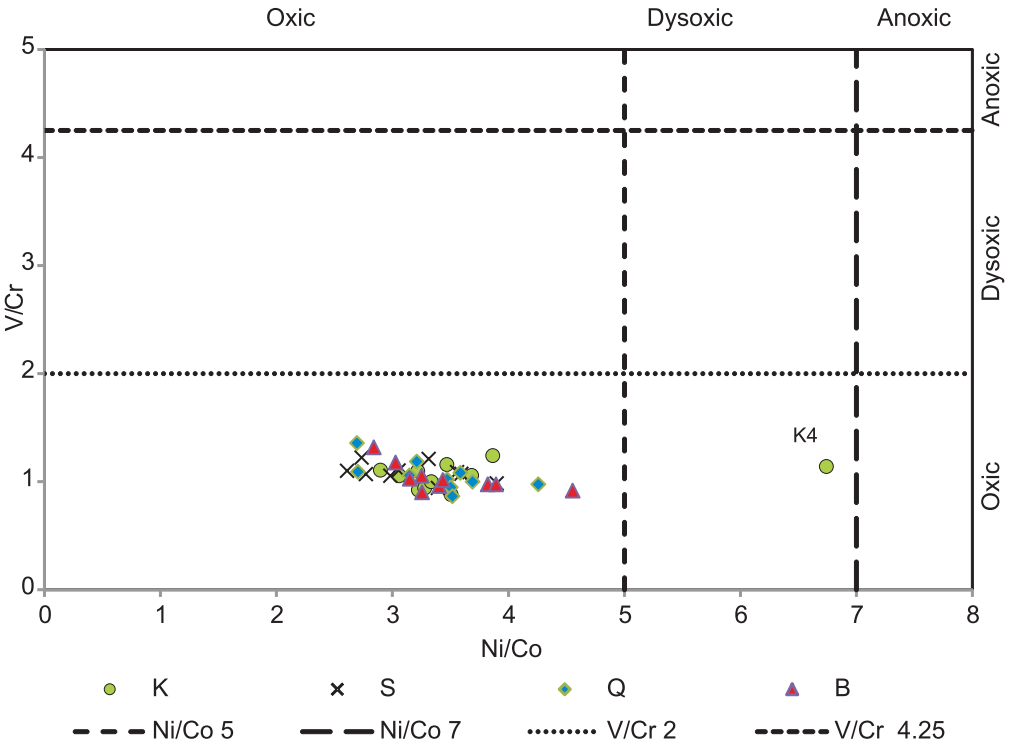

Fig. 11. Crossplots of $\mathrm{Ni} / \mathrm{Co}$ vs $\mathrm{V} / \mathrm{Cr}$ redox indices

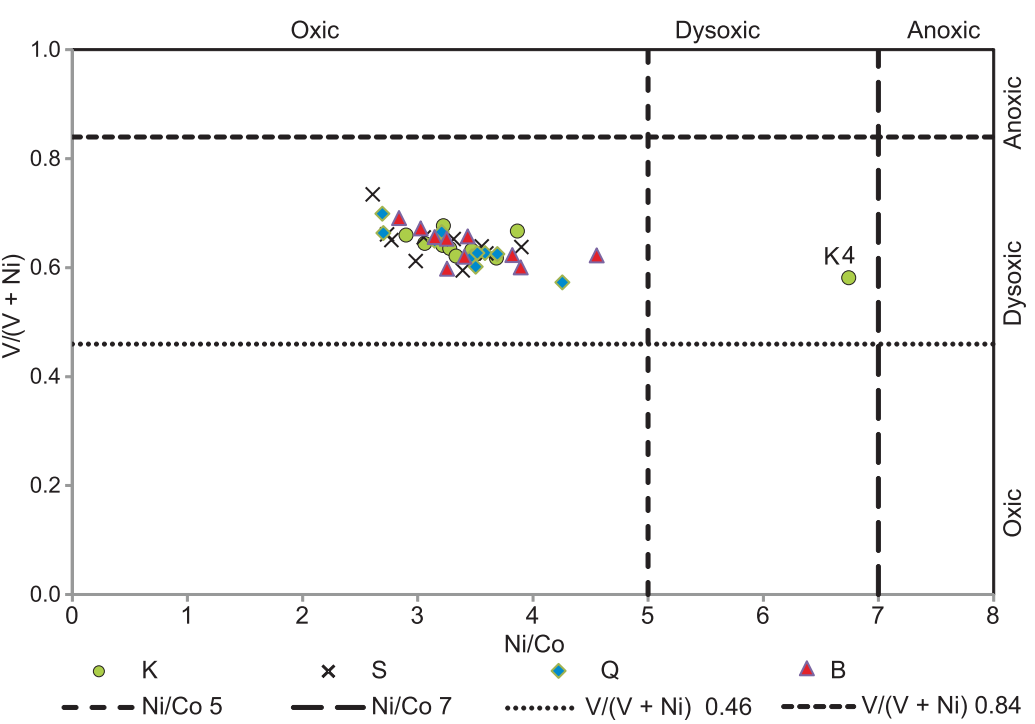

Fig.12. Crossplots of $\mathrm{Ni} / \mathrm{Co}$ vs $\mathrm{V} /(\mathrm{V}+\mathrm{Ni})$ redox indices

All the analysed samples represent similar lithologies (claystones and sandy claystones).

Vertical variations in the palaeontological record refer to sea level and salinity changes. Cyclic sedimentation and consequent variability of the faunal spectrum in marine horizons are related to changes in environmental conditions, marine ingressions, and periodic sea freshening. Several processes have been proposed to control the cyclic sedimentation: autogenic changes in facies and allogenic changes that are mainly related to periodical sea level fluctuations $(>100 \mathrm{~m})$ generated by glacial episodes of the Gondwana tectonic subsidence and climate (Calver, 1968; Ludwig, 1994; Hampson et al., 1999; Joachimski et al., 2006; Suess et al., 2007; Rygel et al., 2008; Waksmundzka, 2013).

The geochemical investigations, presented for the first time for the Dunbarella horizon, focus mainly on geochemical proxies to determine the palaeoredox conditions. Previous studies of the horizons containing remains of freshwater fauna in the aspect of 
the water salinity (e.g., Th/ $\mathrm{K}_{2} \mathrm{O}, \mathrm{P}_{2} \mathrm{O}_{5} / \mathrm{Al}_{2} \mathrm{O}_{3}$ and $\mathrm{Rb} / \mathrm{K}$ ) provided predominantly ambiguous results (Krzeszowska and Kokowska-Pawłowska, 2017).

Most of the Dunbarella marine horizon in the analysed boreholes is represented by intervals containing marine bivalves accompanied by goniatites. The most important species for stratigraphy are Dunbarella papyracea and Anthracoceras vanderbeckei - the marker species for the Dunbarella faunal horizon.

Goniatite-bearing intervals with marine bivalves can indicate a relatively deep-water environment (Kombrink, 2008). If intervals with goniatites form in oxygen-restricted conditions, it can result in enrichment in $\mathrm{U}, \mathrm{Mo}$ and other redox-sensitive trace elements, and high TOC and S contents (Fisher and Wignall, 2001; Kombrink, 2008). Therefore, they can be recognized using geochemical methods. Geochemical studies on Upper Carboniferous marine bands have shown that marked enrichments in redox-sensitive trace elements, and high TOC and $S$ contents were observed in same goniatite levels, for example, in the Gastrioceras listeri Marine Band (Westphalian A, Middlecliff Quarry, England), the Vanderbeckei Marine Band (Westphalian A and B boundary, Rowe borehole, West Midlands, England), the Namurian Goniatites Marine Band of the Geverik well (Netherlands) (Fisher and Wignall, 2001; Kombrink, 2008; Kombrink et al., 2008; Pearce et al., 2010).

The major environmental proxies $\left(\mathrm{DOP}_{\mathrm{t}}, \mathrm{V} / \mathrm{Cr}\right.$, Ni/Co, $\mathrm{TOC}$, TOC, $U$ and $\mathrm{Mo}$ ) in most of the samples representing intervals with goniatite in the Dunbarella horizon indicate oxic conditions during deposition. Similar results were presented for the Westphalian marine bands (Domina, Veldhof and Aegir) of the Netherlands. Those marine bands represent predominantly a Lingula facies characterized by low organic carbon contents (1-2 wt.\%), and mostly lacking significant trace element enrichments (Kombrink, 2008; Kombrink et al., 2008).

Anoxic conditions are suggested only by geochemical indicators calculated for samples from the lowest part of the Kopina 1 borehole. Samples K3 and K4 show generally higher TOC, $\mathrm{DOP}_{\mathrm{t}}$ and $\mathrm{Ni} / \mathrm{Co}$ values than those from other parts of the Dunbarella horizon. In addition, the $U$ and Mo enrichment, the presence of authigenic $U$, and the Mo/ $U$ molar ratios (especially in sample $\mathrm{K} 4$ ) also suggest oxygen-restricted conditions. It is also worth noting that the deposits (sample K2) directly underlying the above-mentioned samples (K3, K4) contain freshwater fauna and show similar geochemistry, suggesting oxygen-restricted conditions.
The samples with brackish and high salinity-tolerant faunas generally show major environmental indices values indicating oxic conditions during deposition, as well as the sample with freshwater fauna or non-assignable remains, and those the lack of fauna.

Palaeontological data allow identification of intervals with similar geochemical characteristics, representing marine, offshore or brackish, and freshwater sedimentation. Thus, the palaeontological study seems to be the only method to dentify the Dunbarella horizon.

\section{CONCLUSIONS}

Palaeontological study of the Dunbarella marine marker horizon showed the presence of macrofauna representing different palaeoenvironments, from marine and brackish (non-marine) to freshwater conditions (cf. Krzeszowska, 2015). Vertical variations of faunal assemblages are related to rapid and probably short-term sea level and salinity changes controlled by marine ingressions and periodic basin freshening.

Geochemical parameters are relatively similar throughout the Dunbarella horizon. They do not show as large fluctuations as the palaeontological record does. The proxies $\left(\mathrm{TOC}, \mathrm{Dop}_{\mathrm{t}}\right.$, redox-sensitive trace element concentrations, $\mathrm{Mo}_{\text {aut }} / \mathrm{U}_{\text {aut. }}, \mathrm{V} / \mathrm{Cr}$, $\mathrm{Ni} / \mathrm{Co}$ ) suggest mostly permanently oxygenated conditions.

Oxygen-restricted conditions are suggested only by the values of geochemical indicators calculated for samples from the lowest part of the Kopina 1 borehole section.

Two complementary, palaeoecological (based on the faunal spectrum) and geochemical studies were applied to determine palaeoenvironmental conditions of the Dunbarella horizon. They have allowed confirming significant changes in palaeo-salinity and relatively constant redox conditions during deposition of the analysed horizon. To make a complete reconstruction of sedimentary environments, an integrated approach, including palaeoecology, geochemistry and sedimentology, should be used.

Acknowledgements. I would like to thank Prof. Z. Sawłowicz, Prof. N. Tribovillard and anonymous Reviewer for their helpful and constructive comments that helped me to improve the paper.

\section{REFERENCES}

Algeo, T.J., 2004. Can marine anoxic events draw down the trace-element inventory of seawater? Geology, 32: 1057-1060.

Algeo, T.J., Lyons, T.W., 2006. Mo-total organic carbon covariation in modern anoxic marine environments: implications for analysis of paleoredox and paleohydrographic conditions. Paleoceanography, 21: PA1016.

Algeo, T.J., Maynard, J.B., 2004.Trace-element behavior and redox facies in core shales of Upper Pennsylvanian Kansas-type cyclothems. Chemical Geology, 206: 289-318.

Algeo, T.J., Maynard, J.B., 2008. Trace-metal covariation as a guide to water-mass conditions in ancient anoxic marine environments. Geosphere, 4: 872-887.
Algeo, T.J., Rowe, H., 2012. Paleoceanographic applications of trace-metal concentration data. Chemical Geology, 324-325: $6-18$.

Algeo, T.J., Tribovillard, N., 2009. Environmental analysis of paleoceanographic systems based on molybdenum-uranium covariation. Chemical Geology, 268: 211-225.

Berner, R.A., 1970. Sedimentary pyrite formation. American Journal of Science, 268: 1-23.

Berner, R.A., Raiswell, R., 1983. Burial of organic carbon and pyrite sulfur in sediments over Phanerozoic time: a new theory. Geochimica et Cosmochimica Acta, 47: 855-862. 
Berner, R.A., Raiswell, R., 1984. C/S method for distinguishing freshwater from marine sedimentary rock. Geology, 12: 365-368.

Brumsack, H-J., 2006. The trace metal content of recent organic carbon-rich sediments: implications for Cretaceous black shale formation. Palaeogeography, Palaeoclimatology, Palaeoecology, 232: 344-361.

Calver, M.A., 1968. Distribution of Westphalian marine faunas in Northern England and adjoining areas. Proceedings of the Yorkshire Geological Society, 37: 1-72.

Calvert, S.E., Pedersen, T.F., 1993. Geochemistry of recent oxic and anoxic marine sediments: implications for the geological record. Marine Geology, 113: 67-88.

Cruse, A.M., Lyons, T.W., 2000. Sedimentology and geochemistry of the Hushpuckney and Upper Tackett shales: cyclothem models revisited. Oklahoma Geological Survey Circular, 103: 185-194.

Dill, H., Teschner, M., Wehner, H., 1988. Petrography, inorganic and organic geochemistry of Lower Permian carbonaceous fan sequences ("Brandschiefer Series") - Federal Republic of Germany: constraints to their palaeogeography and assessment of their source rock potential. Chemical Geology, 67: 307-325.

Dusar, M., 2006. Chokierian. Geologica Belgica, 9: 177-187.

Fisher, Q.J., Wignall, P.B., 2001. Palaeoenvironmental controls on the uranium distribution in an Upper Carboniferous black shale (Gastrioceras listeri Marine Band) and associated strata England. Chemical Geology, 175: 605-621.

Hampson, G., Stollhofen, H., Flint, S., 1999. A sequence stratigraphic model for the Lower Coal Measures (Upper Carboniferous) of the Ruhr district, north-west Germany. Sedimentology, 46: 1199-1231.

Hatch, J.R., Leventhal, J.S., 1992. Relationship between inferred redox potential of the depositional environment and geochemistry of the Upper Pennsylvanian (Missourian) stark shale member of the Dennis Limestone, Wabaunsee County, Kansas, USA. Chemical Geology, 99: 65-82.

Heckel, P.H., Clayton, G., 2006. The Carboniferous System. Use of the new official names for the subsystems, series, and stages. Geologica Acta, 4: 403-407.

Joachimski, M.M., von Bitter, P.H., Buggisch, W., 2006. Constraints on Pennsylvanian glacioeustatic sea-level changes using oxygen isotopes on conodont apatite. Geology, 34: 277-280.

Jones, B., Manning, D.A.C., 1994. Comparison of geochemical indices used for the interpretation of palaeoredox conditions in ancient mudstones. Chemical Geology, 111: 111-129.

Kombrink, H., 2008. The Carboniferous of the Netherlands and surrounding areas; a basin analysis. Geologica Ultraiectina, 294: 1-184.

Kombrink, H., van Os, B.J.H., van der Zwan, C.J., Wong, T.E., 2008. Geochemistry of marine and lacustrine bands in the Upper Carboniferous of the Netherlands. Netherlands Journal of Geosciences, 87: 309-322.

Krzeszowska, E., 2015. New data on the development of the Dunbarella marine marker horizon in the Lublin Coal Basin (Poland). International Journal of Coal Geology, 150-151: 170-180.

Krzeszowska, E., Kokowska-Pawłowska, M., 2017. Geochemical characterization of the freshwater faunal horizons of the Lublin formation from the Lublin Coal Basin. Gospodarka Surowcami Mineralnymi - Mineral Resources Management, 33: 5-30.

Leeder, M.R., 1988. Recent developments in Carboniferous geology; a critical review with implications for the British Isles and N.W. Europe. Proceedings of the Geologists' Association, 99: 73-100.

Leeder, M.R., Raiswell, R., Al-Biatty, H., Mcmahon, A., Hardmann, M., 1990. Carboniferous stratigraphy, sedimentation and correlation of well 48/3-3 in the southern North Sea Basin: integrated use of palynology, natural gamma/sonic logs and carbon/sulfur Geochemistry. Geological Society of London Journal, 147: 287-300.
Leventhal, J.S., 1987. Carbon and sulfur relationships in Devonian shales from the Appalachian Basin as an indicator of environment of deposition. American Journal of Science, 287: 33-49.

Ludwig, A.O., 1994. Cyclic sedimentation and climatically caused sea-level changes in the Late Palaeozoic of Central Europe. Geologische Rundschau, 83: 799-810.

Marynowski, L., Zatoń, M., Rakociński, M., Filipiak, P., Kurkiewicz, S., Pearce, T.J., 2012. Deciphering the upper Famennian Hangenberg Black Shale depositional environments based on multi-proxy record. Palaeogeography, Palaeoclimatology, Palaeoecology, 346-347: 66-86.

Marynowski, L., Pisarzowska, A., Derkowski, A., Rakociński, M., Szaniawski, R., Środoń, J., Cohen, A.S., 2017. Influence of palaeoweathering on trace metal concentrations and environmental proxies in black shales. Palaeogeography, Palaeoclimatology, Palaeoecology, 472: 177-191.

Musiał, Ł., Tabor, T., 2001. Korelacja biostratygraficzna karbonu górnego Polski z innymi obszarami na podstawie makro- i mikrofauny (in Polish). Atlas skamieniałości przewodnich i charakterystycznych. Karbon. Budowa Geologiczna Polski, III, 22-26, Państwowy Instytuty Geologiczny, Warszawa.

Musiał, Ł., Tabor, M., Żakowa, H., 1995. Macrofauna (in Polish). Prace Państwowego Instytutu Geologicznego,148: 23-44.

Narkiewicz, M., 2007. Development and inversion of Devonian and Carboniferous basins in the eastern part of the Variscan foreland (Poland). Geological Quarterly, 51 (3): 231-256.

Pearce, T.J., McLean, D., Martin, J.H., Ratcliffe, K., Wray, D.S., 2010. A whole-rock geochemical approach to the recognition and correlation of "Marine Bands". SEPM Special Publication, 94: 221-238.

Porzycki, J., Zdanowski, A., 1995. Southeastern Poland (Lublin Carboniferous Basin). Prace Państwowego Instytutu Geologicznego, 148: 102-109.

Racka, M., Marynowski, L., Filipiak, P., Sobste, I.M., Pisarzowska, A., Bond, D.P.G., 2010. Anoxic Annulata Events in the Late Famennian of the Holy Cross Mountains (Southern Poland). Geochemical and palaeontological record. Palaeogeography, Palaeoclimatology, Palaeoecology, 297: 549-575.

Racki, G., Baliński, A., Wrona, R., Małkowski, K., Drygant, D., Szaniawski, H., 2012. Faunal dynamics across the Silurian-Devonian positive isotope excursions $\left(\delta^{13} \mathrm{C}, \delta^{18} \mathrm{O}\right)$ in Podolia, Ukraine: comparative analysis of the Ireviken and Klonk events. Acta Palaeontologica Polonica, 57: 795-832.

Raiswell, R., Al-Biatty, H.J., 1989. Depositional and diagenetic $\mathrm{C}-\mathrm{S}-\mathrm{Fe}$ signatures in early Paleozoic normal marine shales. Geochimica et Cosmochimica Acta, 53: 1147-1152.

Raiswell, R., Berner, R.A., 1986. Pyrite and organic matter in Phanerozoic normal marine shales. Geochimica et Cosmochimica Acta, 50: 1967-1976.

Raiswell, R., Buckley, F., Berner, R.A., Anderson, T.F., 1988. Degree of pyritization of iron as a paleoenvironmental indicator of bottom-water oxygenation. Journal of Sedimentary Petrology, 58: 812-819.

Richards, B.C., 2013. Current status of the International Carboniferous Time Scale. Museum of Natural History and Sciences Bulletin, 60: 348-353.

Rimmer, S.M., 2004. Geochemical paleoredox indicators in Devonian-Mississippian black shales, Central Appalachian Basin (USA). Chemical Geology, 206: 373-391.

Rimmer, S.M., Thompson, J.A., Goodnight, S.A., Robl, T.L., 2004. Multiple controls on the preservation of organic matter in Devonian - Mississippian marine black shales: geochemical and petrographic evidence. Palaeogeography, Palaeoclimatology, Palaeoecology, 215: 125-154.

Rygel, M.C., Fielding, Ch.R., Frank, T.D., Birgenheier, L.P., 2008. The magnitude of Late Paleozoic glacioeustatic fluctuations. A synthesis. Journal of Sedimentary Research, 78: 500-511.

Suess, M.P., Drozdzewski, G., Schaefer, A., 2007. Sedimentary environment dynamics and the formation of coal in the Pennsyl- 
vanian Variscan foreland in the Ruhr Basin (Germany, Western Europe). International Journal of Coal Geology, 69: 267-287.

Szczepanik, P., Witkowska, M., Sawłowicz, Z., 2007. Geochemistry of Middle Jurassic mudstones (Kraków-Częstochowa area, southern Poland): interpretation of the depositional redox conditions. Geological Quarterly, 51 (1): 57-66.

Tribovillard, N., Algeo, T.J., Lyons, T., Riboulleau, A., 2006. Trace metals as paleoredox and paleoproductivity proxies: an update. Chemical Geology, 232: 12-32.

Waksmudzka, M.I., 2013. Carboniferous coarsening-upward and non-gradational cyclothems in the Lublin Basin (SE Poland): palaeoclimatic implications. Geological Society Special Publications, 376: 141-175.

WedepohI, K.H., 1991. The composition of the upper earth's crust and the natural cycles of selected metals. Metals in natural raw materials. Natural Resources. In: Metals and their compounds in the environment (ed. E. Merian): 3-17 VCH, Weinheim, Germany.
Wignall, P.B., 1994. Black Shales. Clarendon Press, Oxford.

Wignall, P.B., Myers, K.J., 1988. Interpreting benthic oxygen levels in mudrocks: a new approach. Geology, 16: 452-455.

Wójcik-Tabol, P., 2015. Depositional redox conditions of the Grybów Succession (Oligocene, Polish Carpathians) in the light of petrological and geochemical indices. Geological Quarterly, 59 (4): 603-614.

Zatoń, M., Marynowski, L., Szczepanik, P., Bond, D.P.G., Wignall, P.B., 2009. Redox conditions during sedimentation of the Middle Jurassic (Upper Bajocian-Bathonian) clays of the Polish Jura (south-central Poland): an integrated approach. Facies, 55: 103-114.

Zdanowski, A. ed., 1999. Atlas geologiczny Lubelskiego Zagłębia Węglowego 1:500000 (in Polish). Państwowy Instytut Geologiczny, Warszawa.

Ziegler, P.A., 1989. Evolution of Laurussia - a study in Late Palaeozoic plate tectonics. Kluwer Academic Publishers. Dordrecht, Boston, London. 